\title{
The Role of School Supervisors in Improving the Quality of Junior High School Learning at Oku Selatan District
}

\author{
Rohaya $^{1 *}$, Yasir Arafrat ${ }^{2}$, Alhadi Yan Putra ${ }^{2}$ \\ ${ }^{1}$ Junior high school in Muaradua District, South OKU Regency \\ ${ }^{2}$ Universitas PGRI Palembang \\ *Corresponding Author. Email: rohyanp178@gmail.com
}

\begin{abstract}
This study aims to obtain an overview of the role of school supervisors and supporting and inhibiting factors in improving the quality of junior high school learning in Muaradua District, South OKU Regency. The research informants were school supervisors, school principals and junior high school teachers, while the research subjects were two school supervisors who served in junior high schools. Data collection and recording procedures using observation, interviews, and documentation studies. The data analysis technique used is qualitative data analysis, namely data condensation, data presentation, and conclusions. Checking or checking the validity of the data uses a credibility test by extending observations, observation persistence, triangulation (source, method and time), referential adequacy, and member check. The results of the research obtained were first that school supervisors had a program of monitoring and coaching / mentoring of learning planning even though the implementation had not been maximally and effectively touched all teachers and / or SMP. Second, school supervisors have not carried out monitoring and guidance on the implementation of learning in all junior high schools, both in the classroom and in the implementation of lab / laboratory practices. Third, the monitoring and guidance / guidance of school supervisors on the assessment of learning outcomes is only focused on the implementation of exams in schools, not specifically and specifically monitoring and guiding the assessment of learning outcomes. Internal supporting factors are that the district education office supports the work of school supervisors, encourages school supervisors to be creative, and work professionally. Inhibiting factors are only technical factors, for example there are still various responses from school principals and teachers, some are shocked, afraid, anxious or anxious, worried, even avoiding and inadequate support for facilities because they are new.
\end{abstract}

Keywords : School Supervisor, Education Quality

\section{INTRODUCTION}

Quality assurance of education is the responsibility of external parties, in this case, including local governments. Therefore, regional governments must have internal and external education quality assurance programs and teams that are capable of ensuring the quality of education in education units and in their districts. One of the external parties that has a role in improving the quality of education is school supervisors. School supervisors in the education quality assurance system act as supervisors who supervise learning and managerial learning in educational units. School supervisors act as government officials on the one hand, and as expert and professional positions to ensure the quality of education on the other. The balance of the two roles of school supervisors must be able to improve the quality of learning in educational units.
On the other hand, school supervisors are the supervisors and supervisors of the head of the education unit in the management of learning in the education unit, improving the performance of teachers and education personnel in the education unit in carrying out their main duties. Understand the concept of program development, utilize technology in improving the quality of education. School supervisors as one of the pillars of guaranteeing the quality of learning and education quality externally are required to have personality, social, managerial, academic, educational evaluation and research and development competencies. With that competence, they can carry out their responsibilities to grow their motivation and master the methods and techniques of supervision so that they have a level of readiness to carry out monitoring, supervision, and monitoring tasks. assessment of the performance of school principals 
and teachers as well as other educational personnel, coaching, mentoring and training, reporting and follow-up on the results of supervision. [1] concerning functional positions for School Supervisors and their credit numbers)

The position and function of school supervisors as technical functional in the field of academic and managerial supervision in education units and the main duties of supervisors in the preparation of supervisory programs, implementing guidance, monitoring the fulfillment of national education standards, evaluating teacher and school principal performance, guiding and training teacher professionalism and school principals, and the evaluation of the results of the implementation of the supervision program have not been well understood by some school supervisors as the spearhead of policy makers in improving and guaranteeing the quality of education in the regions. (Permenegpan RB Number 21 of 2010 concerning functional positions of School Supervisors and their credit scores)

The findings in the field show that in OKU Selatan District the position of school supervisors who is appointed lacks competence according to the demands of the legislation, because the recruitment of supervisors is not on the basis of merit but as a waste worker from school principals who have expired their tenure as school principals, school principals who are almost entering retirement period. In addition, the career path of school supervisors is still unclear and is not running as it should be. The guidance and professional development of school supervisors is rarely and even in one year never carried out by the local government, in the form of supervisor training, supervisory special workshows, seminars, workshops and other scientific activities.

The existence of junior high school supervisors in Muaradua sub-district, OKU Selatan district has not carried out their main functions and duties optimally, this is illustrated by the results of interviews with several teachers and SMP principals in Muaradua District. Whereas most junior high school supervisors are not outstanding teachers or school principals and have been trained in advance so that they do not understand and are able to develop supervision according to the demands of laws and regulations, school supervisors do not have a sustainable supervision program, while the role of school supervisors is as stated in [2] regarding the national education system, article 66 mandated the importance of monitoring activities for the implementation of education at all levels and types of education, both by the government and society.
Supervision by the government comes in various forms, one of which is the supervision of education carried out by school supervisors. On the other hand, teachers need guidance and guidance, especially regarding the ability and readiness of teachers in planning lessons, implementing learning, and assessing learning outcomes. Therefore the role of school supervisors in monitoring or fostering and guiding teachers in schools is expected. The role of school supervisors is in line with their main duties as education personnel who are responsible for meeting national education standards as the basis for guaranteeing the quality of education in education units. especially concerning the ability and readiness of teachers in planning lessons, implementing learning, and assessing learning outcomes. Therefore the role of school supervisors in monitoring or fostering and guiding teachers in schools is expected.

The role of school supervisors is in line with their main duties as educational personnel who are responsible for meeting national education standards as the basis for guaranteeing the quality of education in education units. especially concerning the ability and readiness of teachers in planning lessons, implementing learning, and assessing learning outcomes. Therefore the role of school supervisors in monitoring or fostering and guiding teachers in schools is expected. The role of school supervisors is in line with their main duties as educational personnel who are responsible for meeting national education standards as the basis for guaranteeing the quality of education in education units.

The quality of learning in the education unit is the responsibility of the school supervisor. This is in accordance with what was conveyed by [3] that the role of school supervisors is as a guarantor of the quality of education at the educational unit level. In line with the things said by the [4] said that to improve the quality of education in education units, the presence of school supervisors is required. School supervisors are needed because they can motivate teachers to have good performance in carrying out their duties and responsibilities as educators in educational units.

\section{RESEARCH METHODS}

The research method that I use is a qualitative method. The qualitative method was chosen in order to obtain more detailed, objective, thorough, and in-depth information about the role of school supervisors in improving the quality of learning in SMP Muaradua District, South OKU Regency. In addition, the qualitative method will provide broad access or opportunities for researchers to examine in depth, 
detail, intensively, and thoroughly the role of school supervisors, supporting factors and obstacles for school supervisors in improving the quality of junior high school learning in Muaradua District, South OKU Regency through various sources of information. This type of research approach is descriptive, which will study existing problems and work procedures that apply according to technical guidelines. Describe.

This research focuses onThe role of school supervisors in improving the quality of learning in SMP Muaradua Subdistrict, OKU Selatan District is the implementation of the school supervisor's duties in monitoring and coaching learning planning which includes: 1) Preparation of syllabus; 2) Preparation of RPP. Monitoring and coaching of the implementation of learning includes: 1) The number of hours face to face; 2). Availability of learning resources; 3). Use of media and learning resources; 4) Use of learning methods and strategies (learning models). And assessment of learning outcomes includes: 1). Ability to determine assessment techniques; 2). Preparation of assessment instruments; 3). Ability to compile grid questions; 5). And the ability to report the assessment of learning outcomes.

The data collection technique used in this study was the observation carried out on the activities of school supervisors in monitoring and coaching / mentoring junior high school teachers in Muaradua sub-district related to lesson planning, learning implementation, and assessment of learning outcomes as well as supporting and inhibiting factors. Interviews were conducted with two school supervisors, three school principals, and 10 teachers [5]. Documentation study is intended to provide additional information and at the same time strengthen the research results that are confirmative to the data that has been obtained through observation and interviews. Documentation results in the form of images in the form of photos, and other documents related to the implementation of the role of school supervisors in improving the quality of junior high school learning in Muaradua District, South OKU Regency. Documentation is used to strengthen information or data obtained through observation and interviews

Checking and checking the validity of the data in this study using a credibility test (degree of trust) by[6] taking the following steps:

\subsection{Reference adequacy}

The data that has been obtained during the conduct of the research are in the form of voice recordings of interviews from various informants, video recordings, photo documentation, and relevant supervisory documents.

\subsection{Increased persistence}

Increase the writer's persistence by looking carefully and consistently for patterns of relationships and trying to find characteristics and elements that are relevant to the focus of the research

\subsection{Triangulation}

This study uses triangulation of sources, triangulation of techniques / methods, and triangulation of time. Source triangulation was carried out by taking data from various informants including school supervisors who served in SMK as research subjects, the head of the MKPS, school principals, and vocational teachers to see the suitability of the results of interviews obtained from different informants.

\subsection{Membercheck}

Checking the author did after getting some conclusions based on the research results then confirming to the information how far the information or data obtained was in accordance with what was provided by the informant.

\subsection{Extension of observation}

The author's extension of observations is done by returning to the field, conducting observations and interviews with new informants to confirm and confirm some of the research data that has been concluded, so that the data is saturated.

\section{RESULTS AND DISCUSSION}

The role of school supervisors in improving the quality of junior high school learning in Muaradua District, South OKU Regency. The role of school supervisors in carrying out monitoring and guidance / guidance of learning planning.

Based on the results of observations, interview analysis and documentation studies, it can be concluded that school supervisors in carrying out monitoring of learning planning in SMP in Muaradua District, OKU Selatan Regency refer to the supervisor's annual program which contains steps and a monitoring schedule. This is in accordance with the opinion expressed by [6]

Technically before carrying out monitoring, through the Head of the School Supervisory Work Conference (MKPS) facilitates school supervisors to carry out monitoring preparatory meetings for junior high schools, with the agenda of discussing and strengthening the monitoring plan to be carried out, such as the readiness of monitoring instruments both academic and managerial, and other matters. else as needed. Organization is one of the important instruments in realizing maximum work as a school supervisor, always making the organization a forum 
for cooperation and collaboration in every work. According to [7] in carrying out his main roles and duties, a school supervisor should not walk alone, in the sense that he only carries out and fulfills work responsibilities and obligations.

The implementation of school supervisor monitoring of learning planning is carried out based on the school supervisor program as stated in the annual program and the semester program. The affirmation of the importance of the school supervisor program is based on the results of interviews with informants that do not go to school looking for teacher programs, we ourselves school supervisors do not have a program. Based on the results of this study, it can be concluded that school supervisors in carrying out monitoring of SMP learning planning in South OKU Regency refer to the supervisor's annual program which contains monitoring steps and schedules and technically before conducting monitoring, through the Head of the School Supervisory Work Conference (MKPS) facilitating school supervisors to conduct monitoring preparatory meetings for junior high schools.

The results also show that before conducting classroom monitoring, school supervisors directly check the results of lesson planning. School supervisors check the syllabus, check the components in the syllabus, such as competency standards, and basic competencies [7]. The attendance of school supervisors varies from SMP to school. some have often, there are new times both school supervisors come to monitor learning devices [8]. School supervisors monitor the syllabus by looking at the needs of the teacher's program for implementation in class whether it meets student needs. Regardless of whether it is maximal or not, what is clear is that the arrival of the school supervisor monitors it regularly in junior high school, every week, or every month or every semester is a concrete step for school supervisors to help schools or teachers in improving the quality of learning.

In addition, Neagley and [9] reveal that to achieve successful implementation of supervision requires high leadership abilities. Supervisors must be intelligent, trained in educational psychology, attractive, experienced and skilled in managing democratic group processes.

The results of this study can be concluded that the components of the learning planning that are checked by the school supervisor when conducting monitoring at SMP OKU Selatan district are common components including the academic calendar, annual program (Prota), semester program (Prosem), KI analysis / KD, Mapping, Syllabus, RPP, own schedule / face to face schedule, and time allocation, journal, KKM, question bank. While the components in the syllabus include $\mathrm{KI}$, KD, and indicators, in principle, school supervisors have been monitored, although [10] they are still limited to seeing and only questioning the number of KI, KD, and indicators for each component of the syllabus [11] [12] [13].

\section{CONCLUSION AND SUGGESTION}

\subsection{Conclusion}

Based on the discussion of the research results, this research can be concluded as follows:

The role of school supervisors in improving the quality of junior high school learning in Muaradua District, South OKU Regency can be described as follows, first the school supervisor has had a program of monitoring and coaching / guiding learning planning even though its implementation has not been maximally and effectively touched all teachers and / or SMP in South OKU Regency. The two school supervisors have not carried out monitoring and guidance on the implementation of learning in all junior high schools, both in the classroom and in the implementation of laboratory practices. The third is the monitoring and guidance / guidance of school supervisors on the assessment of junior high school learning outcomes in Muaradua District, OKU Selatan Regency, which is only focused on the implementation of exams at schools.

Internal supporting factors are that the district education office supports the work of school supervisors, encourages school supervisors to be creative, and works professionally and involves school supervisors in 124 policy-making related to SMP. From internal school supervisors, there is enthusiasm and motivation to try to understand the characteristics of each SMP, take a different approach to each SMP, always try to be an example, always communicate every problem by sitting together, and avoid any ties that can damage by not receiving a gift envelope. As for external supporting factors, there is a positive response and acceptance or a good reception from some principals and teachers, especially those who want to progress and have understood the duties and functions of school supervisors, as well as responses that do not accept well the arrival of school supervisors at SMP little by little. reduced. While the inhibiting factors for implementing the role of school supervisors in SMP Muaradua Subdistrict, OKU Selatan District, based on the results of the study, it can be concluded that only in the form of technical constraints, for example there are still various responses from school principals and teachers, there are still those who are shocked, afraid, anxious or 
anxious, worried, even avoided, and inadequate support for facilities because it was new, as well as transportation constraints because of the distance to SMP. as well as the response that was not well received by the arrival of school supervisors in SMP gradually decreased. While the inhibiting factors for implementing the role of school supervisors in SMP Muaradua Subdistrict, OKU Selatan District, based on the results of the study, it can be concluded that only in the form of technical constraints, for example there are still various responses from school principals and teachers, there are still those who are shocked, afraid, anxious or anxious, worried, even avoided, and inadequate support for facilities because it was new, as well as transportation constraints because of the distance to SMP. as well as the response that was not well received by the arrival of school supervisors in SMP gradually decreased. While the inhibiting factors for implementing the role of school supervisors in SMP Muaradua Subdistrict, OKU Selatan Regency, based on the results of the study, it can be concluded that only in the form of technical constraints, for example there are still various responses from school principals and teachers, there are still those who are shocked, afraid, anxious or anxious, worried, even avoided, and inadequate support for facilities because it was new, as well as transportation constraints because of the distance to SMP.

\subsection{Suggestion}

To the government, in this case the South OKU District Education Office (Disdik), to immediately recruit prospective school supervisors to complete the required number of school supervisors according to academic qualifications, especially supervisors.

To the supervisors of SMP South OKU Regency, to maximize the implementation of the planned programs, especially the implementation of learning and assessment of learning outcomes, as well as maximizing the potential of MGMP in each competency.

To the principal and teachers at SMP Kematan Muaraduac, OKU Selatan Regency, to always prepare learning tools, implement and assess learning outcomes as well as possible and always respond well and openly to school supervisors every problem that occurs in planning, implementation, and assessment of results learning.

\section{REFERENCES}

[1] Sujana, H N. (2012). Supervisors and Supervision: Understand the main tasks, functions, roles and responsibilities of school supervisors. Cikarang; Binamitra Publishing.
[2] Hendarman. (2015). Principal's Mental Revolution. Bandung: PT Remaja Rosdakarya.

[3] Sudjana, et al. (2013). Teaching Media (Use and Manufacture). Bandung: Sinar Baru Algensindo.

[4] Aedi. 2014. Basics of Educational Management. Yogyakarta: Gosyen Publishing.

[5] .Munir. 2017. Pembelajaran Digital. Bandung: Alfabeta.

[6] Fuady, M. J. (2016). Pengembangan Aplikasi Evaluasi Pembelajaran Online untuk Pendidikan Jarak Jauh. Jurnal Tekno. Vol 26 September 2016, ISSN: 1693-8739.

[7] Sugiyono. (2016). Metode Penelitian Pendidikan: Penelitian Kuantitatif, Kualitatif dan $R \& D$ Bandung: Alfabeta.

[8] Surat Edaran Menteri Pendidikan dan Kebudayaan Nomor 4 Tahun 2020 tentang Pelaksanaan Kebijakan Pendidikan dalam Masa Darurat Penyebaran Covid-19.

[9] D. H. Ristianti. (2017). "Analisis Hubungan Interpersonal Mahasiswa terhadap Dosen dalam Proses Bimbingan Skripsi," Islam. Couns. J. Bimbing. Konseling Islam, vol. 1, no. 1, p. 25.

[10] Undang-Undang No 20 Tahun 2003 tentang Sistem Pendidikan Nasional.

[11]D. H. Ristianti, G. Putrajaya, and I. Fathurrochman. (2020). "Organizational behavior management through group counseling discussions as a radicalism preventive effort," J. Konseling dan Pendidik.

[12] I. Fathurrochman, D. Hariani, Hamengkubuwono, Arsil, M. Amin, and D. H. Ristianti. (2020). "The Development of Student Academic Administration Services in Higher Education," Int. J. Psychosoc. Rehabil., vol. 24, no. 08, pp. 4764-4771.

[13] Malik, R. S. \& Hamied, F. A. (2016). Research methods: A Guide for first time researchers. Bandung: UPI Press 